\title{
MODEL PBL UNTUK MENINGKATKAN HASIL BELAJAR SISWA DALAM PEMBELAJARAN IPS
}

\author{
Lisa Syupriyanti, Taufina
}

Surel: lisavkr@gmail.com

\begin{abstract}
The purpose of this research was improve the students achievement in learning social science used PBL of $4^{\text {th }}$ grade elementary school. Types of this research was classroom action research with qualitative and quantitative approach. Subject of this research were students of $4^{\text {th }}$ grade were 18 people consist of 8 men and 10 women. Research conducted in two cycles with research procedure includes of planning, implementation, observation, and reflection. The result of research was improve a) Lesson plan the cycles of I was $76,78 \%$ and the cycles II of $92,86 \%$ b) Implementation teacher's activity of I cycle was $75 \%$ and II cycle was $92,86 \%$ while implementation students activity of I cycle was 73,22\% and II cycle was $92,86 \%$ c) the students learning outcomes in the I cycle was 75,89 and II cycle was 86,82. It can be concluded that used PBL model can improve students achievement in learning social science of $4^{\text {th }}$ grade at SDN 25 ATS Kota Padang.
\end{abstract}

Keywords: Learning outcomes, Social science, PBL

\begin{abstract}
ABSTRAK
Tujuan dari penelitian ini ialah untuk meningkatkan hasil belajar siswa dlam pemblajaran IPS dngan menggunakn model PBL di kelas IV SD. Jenis penelitian yng digunakan ialah Penelitian Tindakan Kelas dngan menggunakn pndekatan kualitatif dan kuantitatif. Subjek penelitian ialah siswa kelas IV sebanyak 18 orang yang terdiri dari 8 orang laki-laki dan 10 orang perempuan. Pelaksanaan penelitian ini dilakukn dlam dua siklus dengan prosedur penelitian yang terdiri dari perencanaan, pelaksanaan, pengamatan dan refleksi. Hasil penelitian menunjukkan peningkatan dalam segi a) RPP siklus I ialah 76,78\% dan siklus II 92,86\%, b) Pelaksanaan pada aspek guru siklus I ialah $75 \%$ dan siklus II $92,86 \%$ sedangkan pelaksanaan pada aspek siswa siklus I ialah $73,22 \%$ dan siklus II $92,86 \%$, c) Hasil belajar siswa pada siklus I ialah 75,89 dan siklus II 86,82. Kesimpulan penelitian ini ialah dengan menggunakan model PBL dpat meningkatkan hasil blajar siswa dlam pemblajaran IPS di Kelas IV SDN 25 ATS Kota Padang.
\end{abstract}

Kata kunci: Hasil Belajar, Pembelajaran IPS, PBL

\section{PENDAHULUAN}

Pmbelajaran IPS ialah salah satu mata plajaran yng diajarkan sejak mulai dari SD. IPS berperan dalam memfungsionalkan dan merealisasikan ilmu-ilmu sosial yang bersifat teori ke dalam kehidupan nyata yang ada dan berkembang di masyarakat. Menurut Isjoni (2007:21) menyatakan bahwa IPS ialah suatu program penddikan yng secara keseluruhan mempersoalkan manusia antara lingkungan fisik dengan lingkungan sosialnya. Melalui IPS, 
siswa dibentuk menjadi warga negara yang baik dan demokratis serta dapat berpartisipasi dan berperan aktif dalam memecahkan masalah untuk menunjang keputusan hidup bermasyarakat.

Tujuan pmbelajaran IPS adalah untk mendidik dan memberi bekal kepada siswa dalam mengenal konsep-konsep yng berkaitan dngan lingkungan masyrakat dan sekitarnya yang dapat menciptakan warga negara yang demokratis, berfikir kritis dan logis dalam memecahkan suatu permasalahan sosial. Maka dari itu, guru diharapkan mampu untuk mengenalkan konsep-konsep yang berhubungan dengan kehidupan masyarakat dan lingkungan yang ada di sekitar siswa serta mengajarkan siswa untuk mengasah kemampuan dasar yang dimilikinya dengan menggunakan cara atau teknik penyampaian materi yang menarik sehingga pembelajaran tidak menjadi membosankan tetapi menyenangkn bagi siswa. Selain itu, guru juga memberikan kebebasan bagi siswa dalam beraktivitas dan bertindak sebagai fasilitator untuk menciptakan pembelajaran yang aktif, inovatif, kreatif, efektif dan menyenangkan (PAIKEM).

Berdasarkn hasil observasi yng peneliti lakukan di Kelas IV SDN 25 Air Tawar Selatan Kota Padang, peneliti melihat dalam pelaksanaan pembelajaran IPS kemampuan siswa dalam merumuskan suatu masalah masih kurang, keaktifan siswa dlam proses pembelajaran masih kurang, motivasi dan minat siswa dlam blajar masih kurang sehingga pembelajaran menjadi kurang bersemangat, kemampuan kerjasama siswa dalam melakukan tugas kelompok masih rendah, dan kemampuan siswa dalam memecahkan masalah masih rendah.

Akibat dari permasalahan yang ditemukan dlam pemblajaran IPS menyebabkan pda hasil blajar siswa yng masih rendah jika diukur dari kriteria ketuntasan minimum (KKM) yng telah ditentukn. Oleh karena itu, untuk tercapainya pmbelajaran IPS yng diharapkn, maka guru dpat meningkatkn hasil blajar siswa dngan menggunakn model pemblajaran yng bervariasi.

Salah satu model pembeljaran yang dapat digunakan ialah dengan menggunakan model Problem Based Learning (PBL). Menurut Hosnan (2014:298) "Problem Based Learning adalah pembelajaran yang mengunakan masalah nyata (autentik) yng tdak terstruktur dan bersifat terbuka sebagai konteks bagi siswa untuk mengembangkan keterampilan menyelesaikan masalah dan berpikir kritis serta sekaligus membangun pengetahuan baru". Model pembelajaran Problem Based Learning yaitu model pmbelajaran yang dapat mengembangkan siswa untk berpikir kritis dalam memecahkan suatu masalah, aktif dan bekerja sama dalam sebuah kelompok, serta siswa bebas dalam mengemukakan idenya bersama teman yang lain dengan mengaitkan pengalaman kehidupan nyata siswa dengan materi tersebut. 
Berdasarkan latar belakang masalah yang telah dikemukakan di atas, maka rumusan masalah secara umum dalam penelitian ini adalah "Bagaimana Peningkatan Hasil Blajar Siswa dalam Pmbelajaran IPS dngan Menggunakan Model Problem Based Learning (PBL) di Kelas IV SDN 25 Air Tawar Selatan Kota Padang". Sedangkan rumusan masalah secara khusus adalah mendeskripsikan bagaimana rencana pelaksanaan pembelajaran, pelaksanaan pembelajaran, dan peningkatan hasil blajar siswa dlam pemblajaran IPS.

Sesuai dngan rumusan masalah di atas, maka tujuan dari penelitian ini secara umum ialah untuk mendeskripsikan peningkatan hasil blajar siswa dlam pemblajaran IPS dengan menggunakan model Problem Based Learning (PBL) di Kelas IV SDN 25 Air Tawar Selatan Kota Padang. Sedangkan tujuan penelitian ini secara khusus ialah untuk mendeskripsikan bagaimana rencana pelaksanan pemblajaran, pelaksanan pembelajaran, dan peningkatan hasil blajar siswa dlam pemblajaran IPS.

\section{METODE PENELITIAN}

Penelitian ini adalah Penelitian Tindakan Kelas (PTK) dngan mengunakan pndekatan kualitatif dan kuantitatif. Pendekatan kualitatif merupakan pendekatan yang mengungkapkan fakta yang diperoleh peneliti secara langsung di lapangan dengan mendeskripsikan dalam bentuk kata-kata terhadap apa yang terjadi oleh subjek penelitian. Sedangkan pendekatan kuantitatif merupakan pendekatan yang datanya disajikan dalam bentuk angka untuk mendeskripsikan subjek penelitian.

Penelitian dilaksanakan dengan pelaksanaan yang terdiri dari dua siklus. Siklus I terdiri dari 2 kali pertemuan dan Siklus II terdiri dari 1 kali pertemuan. Menurut pendapat Kemmis dan M.C Taggar (dalam Uno, 2011:88) model siklus yang digunakan dalam penelitian tindakan kelas terdiri dari 4 tahapan yaitu perencanan, pelaksanan, pengamatan dan refleksi.

Penelitian ini dilaksanakan di kelas IV SDN 25 Air Tawar Selatan Kota Padang pada semester genap tahun ajaran 2017/2018. Subjek dalam penelitian ini ialah siswa kelas IV SDN 25 Air Tawar Selatan yang berjumlah sebanyak 18 orang yang terdiri dari 8 orang laki-laki dan 10 orang perempuan.

Pada penelitian ini data dikumpulkan dengan menggunakan cara observasi dan tes. Data yang dikumpulkan berupa a) RPP yang dirancang guru sebelum mengajar, b) Pengamatan pelaksanaan pembelajaran terhadap aspek guru dan aspek siswa, c) Hasil blajar siswa. Sumberdata penelitian adalah guru dan siswa kelas IV SDN 25 Air Tawar Selatan Kota Padang.

\section{HASIL PENELITIAN DAN} PEMBAHASAN

\section{Siklus I}

Penelitian dilakukan dengan empat tahapan yaitu perencanan, pelaksanan, pengamatan, dan refleksi. 
Perencanaan pembelajaran disusun berdasarkan langkah model Problem Based Learning pada semester II dngan berpedoman pda KTSP yang dituangkan dalam bentuk RPP. Peneliti berkolaborasi bersama guru kelas IV SDN 25 Air Tawar Selatan Kota Padang untuk menganalisis Rencana Pelaksanaan Pembelajaran yng berupa standar kompetensi, kompetensi dasar, indikator pembelajaran, dan tujuan pembelajaran yang akan dikembangkan. Materi pembelajaran yang dibahas pada siklus I pertemuan 1 adalah permasalahan sosial tentang kemiskinan sedangkan untuk materi pembelajaran yang dibahas pada siklus I pertemuan 2 adalah permasalahan sosial tentang kejahatan. Sebelum pelaksanan pembelajaran berlangsung, adapun yang peneliti siapkan terlebih dahulu yaitu rencana pelaksanaan pemblajaran (RPP), lembar diskusi kelompok (LDK), lembar evaluasi, lembar penilaian afektif (skala sikap) dan kertas HVS yang digunakan siswa untuk membuat peta konsep serta kunci jawaban yang digunakan dalam pembelajaran.

Pelaksanan pembelajaran pada siklus I melalui 3 kegiatan pemblajaran yaitu dimulai dari kegiatan awal, inti, dan akhir. Kegiatan awal diawali dngan mengucapkn salam dan mengkondisikn kelas untk memulai proses pemblajaran. Kemudian peneliti meminta siswa untuk berdoa dan dilanjutkan dengan menyampaikan appersepsi dan tujuan pembelajaran.
Kegiatan inti langkah 1 orientasi siswa pda masalah, guru menjelaskn tujuan pmbelajaran dan membuka skemata siswa terhadap materi yang akan dipelajari selama proses pemblajaran. Langkah 2 mengorganisasikan siswa untuk belajar, guru membagi siswa dlam bentuk 4 kelompok dengan masingmasing kelompok terdiri dari 4-5 orang. Selanjutnya siswa duduk berkelompok sesuai yang telah ditetapkan dan guru membagikan LDK kepada setiap kelompok serta memberikan penjelasan tentang petunjuk cara pengisian LDK. Langkah 3 membimbing penyelidikan individual/kelompok, guru membimbing siswa untuk melakukan penyelidikan dan mengumpulkan informasi yng sesuai dengan masalah yang didapatkan serta memberikan penjelasan untuk menyelesaikan masalah. Langkah 4 mengembangkan dan menyajikn hasil karya, guru meminta siswa untuk berdiskusi dan menyimpulkan hasil dari pemecahan masalah. Langkah 5 menganalisa dan mengevaluasi proses pemecahan masalah, guru memberikan penguatan kepada siswa dan meminta siswa untuk membuat peta konsep. Kegiatan akhir, guru bersama siswa menyimpulkn pembelajaran kemudian dilanjutkan dengan melakukan evaluasi dan mengisi lembar penilaian skala sikap. Setelah itu pembelajaran ditutup dengan berdoa.

Pengamatan dilakukan terhadap

hasil penyusunan Rencana Pelaksanaan Pembelajaran (RPP), 
aspek guru dan aspek siswa. Pengamatan penilaian pada RPP pada siklus I adalah dengan rata-rata $76,78 \%$ sedangkan untuk aspek guru adalah dengan rata-rata $75 \%$ dan untuk aspek siswa dengan rata-rata $73,22 \%$.

Untuk melakukan penilaian hasil blajar siswa dlam pmbelajaran IPS terdiri dari ranah kognitif, afektif dan psikomotor. Hasil blajar siswa pda siklus I dalam aspek kognitif nilai yang diperoleh ialah dengan rata-rata 75,56 , untuk aspek afektif nilai yang diperoleh ialah dengan rata-rata 75,28 sedangkan untuk aspek psikomotor nilai yang diperoleh ialah dengan rata-rata 76,62. Secara keseluruhan nilai yang diperoleh untuk hasil blajar siswa pda siklus I ialah dengan ratarata 75,89 dengan kriteria baik.

Berdasarkan hasil observasi dan tes yng telah dilakukn maka dpat disimpulkn bahwa hasil belajar siswa belum mencapai kriteria keberhasilan yng diinginkn dan kriteria ketuntasan minimum yng telah ditetapkn. Dengan demikian, peningkatan hasil belajar siswa dlam pembelajaran IPS akan peneliti lanjutkan pada siklus II dengan lebih baik sesuai dengan rancangan RPP dengan menggunakan model Problem Based Learning (PBL).

\section{Siklus II}

Penelitian dilakukn dengan empat tahapan yaitu perencanan, pelaksanan, pengamatan, dan refleksi. Penelitian siklus II dilakukn sebanyak 1 kali pertemuan pada hari Rabu tanggal 9 Mei 2018 pukul 07.30-
09.20 WIB dengan alokasi waktu $3 \times 35$ menit per pertemuan.

Perencanaan pembelajaran disusun berdasarkan langkah model Problem Based Learning pada semester II dengan berpedoman pada Kurikulum Tingkat Satuan Pendidikan (KTSP) yang dituangkan dalam bentuk RPP. Peneliti berkolaborasi bersama guru kelas IV SDN 25 Air Tawar Selatan Kota Padang untuk menganalisis Rencana Pelaksanaan Pembelajaran yang berupa standar kompetensi, kompetensi dasar, indikator pembelajaran, dan tujuan pembelajaran yang akan dikembangkan. Materi pembelajaran yang dibahas pada siklus II pertemuan 1 adalah permasalahan sosial tentang kenakalan remaja. Sebelum pelaksanaan pembelajaran berlangsung, adapun yang peneliti siapkan terlebih dahulu yaitu rencana pelaksanaan pembelajaran (RPP), lembar diskusi kelompok (LDK), lembar evaluasi, lembar penilaian afektif (skala sikap) dan kertas HVS yang digunakan siswa untuk membuat peta konsep serta kunci jawaban yang digunakan dalam pembelajaran.

Pelaksanan pemblajaran pada siklus II melalui 3 kegiatan pemblajaran yaitu dimulai dari kegiatan awal, inti, dan akhir. Kegiatan awal diawali dngan mengucapkn salam dan mengkondisikn kelas untuk memulai proses pmbelajaran. Kemudian peneliti meminta siswa untuk berdoa dan dilanjutkan dengan 
menyampaikan appersepsi dan tujuan pembelajaran.

Kegiatan inti langkah 1 orientasi siswa pda masalah, guru menjelaskn tujuan pembelajaran dan membuka skemata siswa terhadap materi yang akan dipelajari selama proses pembelajaran. Langkah 2 mengorganisasikan siswa untuk belajar, guru membagi siswa dlam bentuk 4 kelompok dngan masingmasing kelompok terdiri dari 4-5 orang. Selanjutnya siswa duduk berkelompok sesuai yang telah ditetapkan dan guru membagikan LDK kepada setiap kelompok serta memberikan penjelasan tentang petunjuk cara pengisian LDK. Langkah 3 membimbing penyelidikan individual/kelompok, guru membimbing siswa untuk melakukan penyelidikan dan mengumpulkan informasi yang sesuai dengan masalah yang didapatkan serta memberikan penjelasan untuk menyelesaikan masalah. Langkah 4 mengembangkan dan menyajikan hasil karya, guru meminta siswa untuk berdiskusi dan menyimpulkan hasil dari pemecahan masalah. Langkah 5 menganalisa dan mengevaluasi proses pemecahan masalah, guru memberikan penguatan kepada siswa dan meminta siswa untuk membuat peta konsep. Kegiatan akhir, guru bersama siswa menyimpulkan pembelajaran kemudian dilanjutkan dengan melakukan evaluasi dan mengisi lembar penilaian skala sikap. Setelah itu pembelajaran ditutup dengan berdoa.
Pengamatan dilakukan terhadap hasil penyusunan Rencana Pelaksanaan Pembelajaran (RPP), aspek guru dan aspek siswa. Pengamatan penilaian pada Rencana Pelaksanaan Pmbelajaran (RPP) pada siklus II adalah dengan rata-rata 92,86\% sedangkan untuk aspek guru adalah dengan rata-rata $92,86 \%$ dan untuk aspek siswa dengan rata-rata $92,86 \%$.

Penilaian hasil blajar siswa dlam pmbelajaran IPS terdiri dari ranah kognitif, afektif dan psikomotor. Hasil blajar siswa pada siklus II dlam aspek kognitif rata-rata yang diperoleh yaitu 87,11, untuk aspek afektif rata-rata yang diperoleh yaitu 87,22, sedangkan untuk aspek psikomotor rata-rata yang diperoleh yaitu 86,12. Secara keseluruhan nilai yang diperoleh untuk hasil blajar siswa pda siklus II ialah dengan ratarata 86,82 dngan kriteria sangat baik.

Berdasarkan hasil observasi dan tes yang telah dilakukan maka dapat disimpulkan bahwa hasil blajar siswa sudah mencapai kriteria keberhasilan yng diinginkn dan kriteria ketuntasan minimum yng telah ditetapkn. Dengan demikian, peningkatan hasil blajar siswa dlam pmbelajaran IPS dengan menggunakn model Problem Based Learning (PBL) di kelas IV SDN 25 Air Tawar Selatan sudah berhasil.

\section{Pembahasan}

Berdasarkan hasil penelitian pelaksanan pmbelajaran IPS dengan menggunakan model Problem Based Learning (PBL) pada siklus I ini 
mengacu pada materi mengenal permasalahan sosial di daerahnya. Sebelum melaksanakan proses pembelajaran guru terlebih dahulu membuat rancangan pembelajaran dlam bentuk RPP. RPP pada siklus I disajikan dalam $2 \mathrm{x}$ pertemuan dengan waktu pelaksanaan selama 3 x 35 menit setiap pertemuannya.

Berdasarkan catatan hasil penelitian pada siklus I peneliti menemukan beberapa kekurangan ialah : 1) Pada aspek pemilihan materi ajar, materi ajar yang diberikan belum sesuai dengan karakteristik siswa dan tujuan pembelajaran karena hasil belajar tidak tercapai dengan tujuan pmbelajaran yang diinginkan. 2) Pada aspek pengorganisasian materi, cakupan materi yang diberikan belum luas dan belum sesuai dengan alokasi waktu yang direncanakan karena materi yang diberikan masih sempit dan penyampaian materi yang tidak sesuai dengan alokasi waktu yng direncanakan. 3) Pada aspek kejelasan proces pmbelajaran, langkah-langkah pemblajaran belum sesuai dngan alokasi waktu serta belum jelas dan rinci karena penggunaan waktu yang tidak efektif saat melakukan tugas kelompok. 4) Pada aspek teknik pembelajaran, teknik pembelajaran yng digunakan belum sesuai dengan karakteristik siswa karena siswa masih belum terbiasa dngan teknik pembelajaran yang digunakan oleh guru. 5) Pada aspek kelengkapan instrumen, soal belum disertai dengan pedoman penskoran yang lengkap.

Menurut Majid (2014:125) yang menyatakan bahwa RPP ialah suatu rencana yng menggambarkan prosedur dan pengorganisasian dalam pembelajaran agar tercapainya satu KD yng telah ditetapkn dalam standar isi dan dijabarkan melalui silabus.

Berdasarkan perencanaan yang telah disusun, pelaksanaan pmbelajaran dilaksanakan sesuai dengan yang telah direncanakan. Pada siklus I dilakukn dlam 2x pertemuan dengan waktu pelaksanaan 3x35 menit setiap pertemuannya.

Berdasarkan diskusi peneliti dngan guru kelas IV SDN 25 Air Tawar Selatan Kota Padang ditemukan beberapa hal yaitu : 1) Pada aspek kegiatan mengkondisikan siswa untuk belajar, suasana kelas belum kondusif untuk memulai pembelajaran yang dikarenakan masih terdapat anak yang bermain-main dan keluar masuk kelas ketika pembelajaran akan berlangsung. Pada aspek kegiatan bersiap untuk blajar, siswa belum mendengarkan namanya dipanggil saat guru melakukan absensi karena guru hanya melakukan absensi secara keseluruhan saja. 2) Pada aspek orientasi siswa pada masalah, guru belum menyampaikan tujuan pembelajaran dngan bahasa yng jelas dan mudah dipahami oleh siswa. 3) Pada aspek mengorganisasikan siswa untuk belajar, guru belum meminta siswa untk dduk berkelompok sesuai dngan yang telah ditetapkan dan belum menjelaskan petunjuk pengisian LDK dengan bahasa yang mudah dipahami siswa. 4) Pada aspek membimbing penyelidikan individual/kelompok, guru belum membimbing siswa untk 
melakukan penyelidikan dan bertukar pendapat dalam kelompok tentang akibat dan cara mengatasinya permasalahan sosial tersebut. 5) Pada aspek mengembangkan dan menyajikan hasil karya, guru belum meminta siswa untuk menyimpulkan dari hasil pemecahan masalahnya. 6) Pada aspek menganalisa dan mengevaluasi proses pemecahan masalah, guru tidak memberikan penguatan kepada siswa terhadap materi yng telah dipelajarinya. 7) Pada kegiatan akhir guru belum membimbing siswa untk menyimpulkan pembelajaran.

$$
\text { Berdasarkan catatan pada }
$$

lembar observasi dan diskusi peneliti dengan observer penyebab belum tercapainya hasil belajar secara maksimal pada siklus I adalah siswa masih banyak belum aktif dalam proses pembelajaran serta alokasi waktu yang masih kurang dimanfaatkan sebaik mungkin. Setelah diperhatikn data hasil penelitian yng berkaitan dngan evaluasi pemblajaran, nilai yng diperoleh siswa masih dibawah kriteria ketuntasan belajar yang diinginkan.

Dari analisis penelitian siklus I, nilai rata-rata yng diperoleh pda evaluasi aspek kognitif siklus I pertemuan 1 yaitu 73,33 dan nilai rata-rata yng diperoleh pda evaluasi aspek kognitif siklus 1 pertemuan 2 yaitu 77,78 . Pada aspek afektif nilai rata-rata yng diperoleh pada siklus I pertemuan 1 adalah 73,33 dan nilai rata-rata yang diperoleh pda aspek afektif siklus I pertemuan 2 adalah
77,22 . Sedangkan untuk aspek psikomotor nilai rata-rata yng diperoleh pda siklus I pertemuan 1 adalah 74,53 dan nilai rata-rata yang diperoleh pada aspek psikomotor siklus I pertemuan 2 adalah 78,70.

Berdasarkan hasil analisis nilai yang dilakukan pada aspek kognitif, afektif dan psikomotor terhadap hasil blajar siswa pda siklus I nilai rata-rata yang diperoleh adalah 75,89 dengan 9 orang anak yang belum mencapai hasil belajar yang diharapkan.

Berdasarkan paparan hasil data pengamatan hasil blajar siswa pda siklus I, maka direncanakan untuk dapat melakukan perbaikan pada pembelajaran IPS berikutnya pada siklus II. Perbaikan-perbaikan tindakan pda siklus II dapat dilakukn dengan mengupayakan peningkatan pemahaman siswa (kognitif) terhadap materi yang diberikan dngan cara memperluas cakupan materi yang diajarkan. Selain itu, upaya perbaikan dalam peningkatan hasil belajar siswa pada aspek afektif dapat dilakukan agar siswa lebih mengaplikasikannya dalam kehidupan sehari-hari seperti halnya juga dengan aspek psikomotor. Menurut Jihad (2012:15), "Hasil belajar adalah kemampuan yang dimiliki siswa setelah menjalani proses belajar".

Perencanaan pembelajaran pada siklus II tdak jauh berbeda dngan siklus I. Berdasarkn hasil pengamatan perencanaan pembelajaran pda siklus II mendapatkn kualifikasi sngat baik (SB) karena ada beberapa aspek yang mengalami peningkatan seperti pda aspek pemilihan materi ajar telah 
sesuai dngan tujuan pmbelajaran dan karakteristik siswa, pda aspek teknik pembelajaran telah sesuai dengan karakteristik siswa, dan pda aspek kelengkapan instrumen soal sudah disertai dengan pedoman penskoran yang lengkap. Hasil penilaian Rencana Pelaksanaan Pembelajaran (RPP) pada siklus II diperoleh dengan nilai $92,86 \%$ dengan kualifikasi sangat baik (SB). Menurut Muslich (2009:53) menyatakan bahwa Rencana Pelaksanaan Pembelajaran ialah suatu rancangan pembelajaran yang disusun perunit mata pelajaran yang ditetapkan guru untuk mengajar dalam pemblajaran di kelas".

Berdasarkan pemaparan data diatas, dpat disimpulkn bahwa perencanaan pembelajaran IPS dengan menggunakan model Problem Based Learning (PBL) telah terlaksana dengan kualifikasi sangat baik (SB) pada siklus II.

Berdasarkn perencanan yng telah disusun, pelaksanan pmbelajaran dilakukn sesuai dngan apa yng telah direncanakn yng disajikn dlam $1 \mathrm{x}$ pertemuan. Pelaksanan pembeljaran pda siklus II sudah terlaksana dengan baik, tetapi masih ada beberapa deskriptor yang belum muncul seperti guru belum memberikan penjelasan tentang cara pengisian LDK dengan menggunakan bahasa yang mudah dipahami siswa dan guru belum membimbing siswa untk menyimpulkan pembelajaran yang telah dipelajari.

Berdasarkan hasil pengamatan penelitian pada siklus II dapat dilihat hasil penilaian pada aspek guru adalah 92,86\% dan untuk hasil penilaian pada aspek siswa adalah 92,86\% dengan kualifikasi sangat baik (SB).

Berdasarkan hasil belajar siswa yang diperoleh setelah melakukan evaluasi jika dilihat dari segi aspek kognitif pada siklus II adalah 87,11 dengan kualifikasi sangat baik (SB), aspek afektif pada siklus II adalah 87,22 dengan kualifikasi sangat baik (SB), dan aspek psikomotor pada siklus II adalah 86,12 dengan kualifikasi sangat baik (SB). Dilihat berdasarkan kualifikasi keberhasilan belajar sebanyak 18 anak, terdapat 15 orang yang mencapai kriteria ketuntasan $(83,33 \%)$ dan 3 orang yang belum mencapai kriteria ketuntasan $(16,67 \%)$.

Berdasarkan perencanaan dan proses pelaksanaan pembeljaran yang diperoleh pda siklus II, maka pelaksanan pmbelajaran pda siklus II telah terlaksana dngan sngat baik dan peneliti telah berhasil dalam meningkatkn hasil blajar siswa dlam pembelajaran IPS dengan menggunakn model problem based learning (PBL) di kelas IV SDN 25 Air Tawar Selatan Kota Padang.

\section{SIMPULAN}

Pelaksanan pembeljaran IPS dngan menggunakan model Problem Based Learning (PBL) dapat diamati dari segi aspek guru dan aspek siswa. Skor yng diperoleh untuk aspek guru pda siklus 1 adalah $75 \%$ dengan kualifikasi cukup mengalami peningkatan menjadi $92,86 \%$ dengan kualifikasi sngat baik pda siklus II. 
Sedangkan skor yng diperoleh untuk aspek siswa pada siklus 1 adalah 73,22\% dngan kualifikasi cukup baik mengalami peningkatan menjadi 92,86\% dngan kualifikasi sngat baik pada siklus II. Pelaksanaan pembelajaran IPS dngan menggunakn model Problem Based Learning (PBL) sudah termasuk ke dlam kualifikasi sangat baik.

Penggunaan model Problem

Based Learning (PBL) dalam pembelajaran IPS di Kelas IV SDN 25 Air Tawar Selatan Kota Padang dapat meningkatkan hasil blajar siswa. Hal ini dpat dilihat dari rekapitulasi penilaian hasil blajar siswa pada siklus II lebih tinggi jika dibandingkan dngan rekapitulasi hasil belajar siswa pada siklus I yaitu 75,89 dngan kualifikasi baik mengalami peningkatan menjadi 86,82 dengan kualifikasi sngat baik. Rekapitulasi hasil penilaian siswa pda siklus I juga sudah mengalami peningkatan pada siklus II karena siswa sudah banyak memperoleh nilai di atas kriteria ketuntasan minimum (KKM) yng sudah ditentukan.

\section{DAFTAR RUJUKAN}

Hosnan. 2014. Pendekatan Saintific dan Kontekstual dalam Pembelajaran Abad 21. Jakarta: Ghalia Indonesia.

Isjoni. 2007. Integrated Learning. Pekanbaru: Falah Production.

Jihad, Asep, dkk. 2012. Evaluasi Pembelajaran. Yogyakarta: Multi Pressindo.
Majid. 2014. Pembelajaran Tematik Terpadu. Bandung: PT Remaja Rosdakarya.

Muslich, Masnur. 2009. KTSP Pembelajaran Berbasis Kompetensi dan Kontekstual. Jakarta: Bumi Aksara

Uno, Hamzah B. 2011. Menjadi Peneliti PTK yang Profesional. Jakarta: Bumi Aksara. 